\title{
Lamellarin O, a Pyrrole Alkaloid from an Australian Marine Sponge, Ianthella sp., Reverses BCRP Mediated Drug Resistance in Cancer Cells
}

\author{
Xiao-Cong Huang ${ }^{1, \dagger}$, Xue Xiao ${ }^{1, \dagger}$, Yun-Kai Zhang ${ }^{2}$, Tanaji T. Talele ${ }^{2}$, Angela A. Salim ${ }^{1}$, \\ Zhe-Sheng Chen ${ }^{2, *}$ and Robert J. Capon ${ }^{1, *}$
}

1 Division of Chemistry and Structural Biology, Institute for Molecular Bioscience, The University of Queensland, Brisbane QLD 4072, Australia; E-Mails: xiaocong.huang@uqconnect.edu.au (X.-C.H.); xue.xiao@imb.uq.edu.au (X.X.); a.salim@imb.uq.edu.au (A.A.S.)

2 Department of Pharmaceutical Sciences, College of Pharmacy and Health Sciences, St. John's University, Queens, NY 11439, USA; E-Mails: helloyunyun@live.com (Y.-K.Z.); talelet@stjohns.edu (T.T.T.)

$\dagger$ These authors contributed equally to this work.

* Authors to whom correspondence should be addressed; E-Mails: chenz@stjohns.edu (Z.-S.C.); r.capon@uq.edu.au (R.J.C.); Tel.: +1-718-990-1432 (Z.-S.C.); +61-7-3346-2979 (R.J.C.); Fax: +1-718-990-1877 (Z.-S.C.); +61-7-3346-2090 (R.J.C.).

Received: 29 May 2014; in revised form: 13 June 2014 / Accepted: 16 June 2014 / Published: 27 June 2014

Abstract: ATP binding cassette (ABC) transporters, such as P-gp, BCRP and MRP1, can increase efflux of clinical chemotherapeutic agents and lead to multi-drug resistance (MDR) in cancer cells. While the discovery and development of clinically useful inhibitors has proved elusive to date, this molecular target nevertheless remains a promising strategy for addressing and potentially overcoming MDR. In a search for new classes of inhibitor, we used fluorescent accumulation and efflux assays supported by cell flow cytometry and MDR reversal assays, against a panel of sensitive and MDR human cancer cell lines, to evaluate the marine sponge co-metabolites 1-12 as inhibitors of P-gp, BCRP or MRP1 initiated MDR. These studies identified and characterized lamellarin $\mathrm{O}(\mathbf{1 1})$ as a selective inhibitor of BCRP mediated drug efflux. A structure-activity relationship analysis inclusive of the natural products 1-12 and the synthetic analogues 13-19, supported by in silico docking studies, revealed key structural requirements for the lamellarin $\mathrm{O}$ (11) BCRP inhibitory pharmacophore. 
Keywords: ABC transporter; multidrug resistance; cancer; P-glycoprotein; BCRP; MRP1; lamellarin $\mathrm{O}$; marine natural products

\section{Introduction}

Cancer is the leading cause of death and represents a large diverse group of diseases, of which some can spread to other sites of the body and result in systemic metastasis. The only effective therapy for metastasis is chemotherapy, which all too frequently fails due to innate or acquired multi-drug resistance (MDR). Historically, the over-expression of three ATP binding cassette (ABC) transporters, P-glycoprotein (P-gp) [1,2], breast cancer resistant protein (BCRP) [3] and/or multi-drug resistance protein 1 (MRP1) [4], have been correlated with many occurrences of MDR. Over-expression of these proteins in cancer cells can lead to premature efflux of chemotherapeutic agents, compromising treatments. The past three decades have seen numerous efforts to overcome MDR caused by P-gp, BCRP and MRP1, with direct inhibition believed to be the most promising solution. Unfortunately, although three generations of P-gp inhibitors have been developed [5], none have proved to be clinically useful. Despite these disappointing results, the need to discover clinically effective inhibitors remains as compelling as ever [6], with marine natural products representing an attractive source of bioactive chemical diversity.

The search for marine natural products as inhibitors of ABC transporters commenced some decades ago, and includes a 1992 report by Prinsep et al. [7] on tolyporphin from the blue-green alga Tolypothrix nodosa Bharadwaja, which increased the cytotoxicity of doxorubicin and vinblastine in P-gp overexpressing SK-VLB cells [7]. Following this discovery, at least a dozen classes of marine metabolites have been reported with P-gp, BCRP or MRP1 inhibitory activity from sponges [8,9], bryozoans [10], gorgonians [11], ascidians [12], sea pens [13], antinomycetes [14] as well as algae [15] and tunicates [16].

Our prior investigations into metabolites of southern Australian and Antarctic marine invertebrates, algae and microbes, have led to the discovery of a number of very promising P-gp inhibitor scaffolds, including diketopiperazines from the marine-sediment derived actinomycete Nocardiopsis sp. (CMB-M0232) [17], alkaloids from tunicates of the genus Didemnum [18], and bromoterpenes from the red alga Laurencia filiformis [19]. This report describes our evaluation of the ABC transporter inhibitory properties of a suite of alkaloids (1-12, Figure 1) isolated from a southern Australian marine sponge, Ianthella sp. (CMB-01245). 
Figure 1. Metabolites isolated from Ianthella sp. (CMB-01245).<smiles>CC(=O)C1(O)NC(=O)C(c2ccc(O)cc2)=C1c1ccc(O)cc1</smiles>

(1) $\mathrm{R}=\mathrm{H}$
(2) $\mathrm{R}=\mathrm{Et}$<smiles>CC(=O)C1(O)OC(=O)C(c2ccc(O)cc2)=C1c1ccc(O)cc1</smiles>

(7) $\mathrm{R}=\mathrm{H}$

(8) $\mathrm{R}=\mathrm{Me}$<smiles>[R]CN1C(=O)C(c2ccc(O)cc2)=C(c2ccc(O)cc2)[C@@]1(O)C(C)=O</smiles>

(3) $\mathrm{R}=\mathrm{OMe}$

(4) $\mathrm{R}=\mathrm{OEt}$

(5) $\mathrm{R}=\mathrm{CO}_{2} \mathrm{Et}$<smiles>CC(=O)c1[nH]cc(-c2ccc(O)cc2)c1-c1ccc(O)cc1</smiles>

(12)<smiles>[R7]Oc1ccc(C(=[R])Cn2cc(-c3ccc(O)cc3)c(-c3ccc(O)cc3)c2C(C)=O)cc1</smiles>

(9) $\mathrm{R}^{1}=\mathrm{H}, \mathrm{R}^{2}=\mathrm{O}$

(10) $\mathrm{R}^{1}=\mathrm{H}, \mathrm{R}^{2}=\mathrm{H}, \mathrm{OH}$

(11) $R^{1}=M e, R^{2}=O$<smiles>COc1ccc(C(=O)CN2C(=O)C(c3ccc(O)cc3)=C(c3ccc(O)cc3)C2(O)C(C)=O)cc1</smiles>

(6)

\section{Results and Discussion}

\subsection{Cytotoxicity of 1-12 against SW620 and SW620 Ad300}

Prior to investigating the interaction between 1-12 and P-gp we assessed cytotoxicity against SW620 and the MDR (P-gp over-expressing) daughter SW620 Ad300 cell line, to establish the non-cytotoxic concentration required for such studies. This study demonstrated that ianthellidones 1-8 and lamellarins 9-10 and 12 were non-cytotoxic towards SW620 and SW620 Ad300 $\left(\mathrm{IC}_{50}>30 \mu \mathrm{M}\right)$, while lamellarin $\mathrm{O}$ (11) exhibited comparable and moderate cytotoxicity towards both SW620 $\left(\mathrm{IC}_{50} 22.0 \mu \mathrm{M}\right.$ ) and SW620 Ad300 ( $\mathrm{IC}_{50} 22.3 \mu \mathrm{M}$ ) (Supplementary Table S1), with the maximal concentration for $>80 \%$ survival of SW620 and SW620 Ad300 cells being $15 \mu \mathrm{M}$.

\subsection{Lamellarin O (11) as a P-gp Inhibitor in SW620 Ad300 Cancer Cells (Calcein AM Assay)}

The Calcein AM accumulation assay (96-well plate format, Section 3.3) [19] was used as the primary screen to assess P-gp inhibitory properties of 1-12, with a compound designated as an inhibitor if a $20 \mu \mathrm{M}$ treatment increased calcein fluorescence $\geq 30 \%$ of that exhibited by a $100 \mu \mathrm{M}$ treatment with the positive control verapamil. While the majority of metabolites tested did not exhibit inhibitory activity against P-gp, 11 displayed a moderate response (85\% of the positive control) (Figure 2), an observation confirmed by cell flow cytometry (Sections 2.3 and 2.4) and MDR reversal (Section 2.5) assays. 
Figure 2. Effect of 1-12 on the accumulation of calcein AM. SW620 Ad300 cells in a 96-well micro-titer plate $\left(5 \times 10^{4}\right.$ per well) were cultured at $37{ }^{\circ} \mathrm{C}$ in $5 \% \mathrm{CO}_{2}$ for $48 \mathrm{~h}$ after which they were treated with either 1-12 $(20 \mu \mathrm{M})$, or the positive control verapamil $(100 \mu \mathrm{M})$, and incubated for $15 \mathrm{~min}$. Cells were then treated with calcein AM $(0.25 \mu \mathrm{M})$ and incubated for a further $30 \mathrm{~min}$. Fluorescence of the calcein AM hydrolysis product calcein was quantified (POLARstar Omega multimode plate reader) and displayed in Figure 2 as the mean value \pm SEM of two independent experiments performed in duplicate $(* p<0.05)$, with the dashed line corresponding to the PBS negative control.

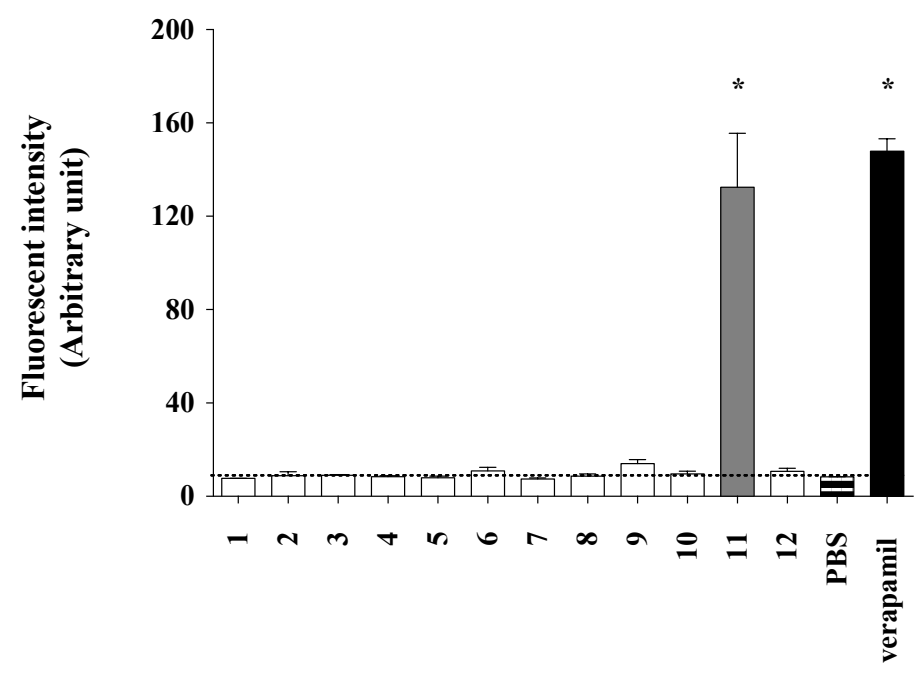

Figure 3. Effect of 9-12 on accumulation of calcein AM in SW620 Ad300 cells using flow cytometry. SW620 Ad300 cells were incubated with calcein AM $(0.25 \mu \mathrm{M})$ with or without 9-12 $(20 \mu \mathrm{M})$, or the positive control verapamil $(20 \mu \mathrm{M})$, after which cells were washed twice with ice-cold PBS and the intracellular calcein fluorescence levels quantified using flow cytometry (Section 3.4). The histogram results (Y-axis represents cell counts with the maximum as 400) for 9-12 and verapamil are illustrated, with data for other metabolites reported in Supplementary Table S2.

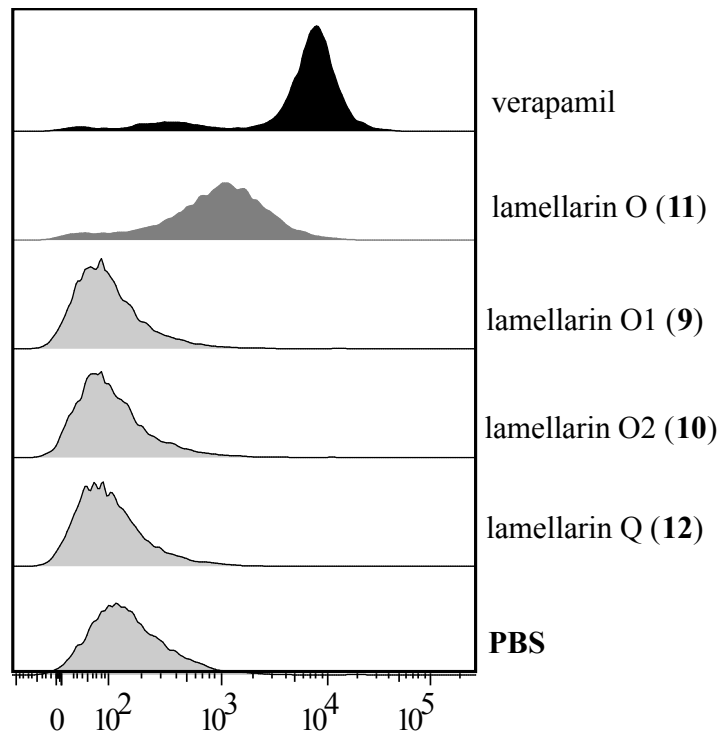

Fluorescent intensity 


\subsection{Lamellarin O (11) as a P-gp Inhibitor in SW620 Ad300 Cells (Calcein AM by Cell Flow Cytometry)}

Cell flow cytometry is an established methodology that when coupled with the Calcein AM assay provides a reliable and accurate means to quantify P-gp inhibitors [20]. Calcein AM assay coupled with cell flow cytometry (Section 3.4) yielded results that were in accord with those detailed above (96-well plate format, Section 2.2) and confirmed that $11(20 \mu \mathrm{M})$ exhibited a moderate (5.1-fold) inhibitory effect on the accumulation of calcein AM from SW620 Ad300 cells (Figure 3 and Supplementary Table S2), with the remaining co-metabolites exhibiting no inhibitory activity ( $<1.0$ fold).

Figure 4. Effect of lamellarin O (11) and verapamil on accumulation (A) and efflux (B) of Hoechst 33342 in SW620 Ad300 using flow cytometry. SW620 Ad300 cells were incubated with or without Hoechst $33342(60 \mu \mathrm{M})$, in the absence or presence of $11(20 \mu \mathrm{M})$, or verapamil $(20 \mu \mathrm{M})$, for $30 \mathrm{~min}$. After incubation cells were washed twice with ice-cold PBS, and intracellular calcein fluorescent intensity measured by flow cytometry (accumulation, Figure A). In an efflux phase assay SW620 Ad300 cells were further incubated in Hoechst 33342-free medium, with or without $11(20 \mu \mathrm{M})$, or verapamil $(20 \mu \mathrm{M})$ for $1 \mathrm{~h}$. After which cells were washed as indicated above for the accumulation phase, and intracellular calcein fluorescent intensity measured by flow cytometry (Figure B). The accumulation and efflux phase increase in intracellular fluorescence mediated by $\mathbf{1 1}$ (thin dashed line) and verapamil (thin solid line), compared with the negative controls of PBS with Hoechst 33342 (heavy solid line), were 2.5-fold and 1.4-fold, and 2.3-fold and 3.8-fold respectively. Heavy dashed line illustrates baseline intracellular fluorescence of SW620 Ad300 cells without Hoechst 33342.

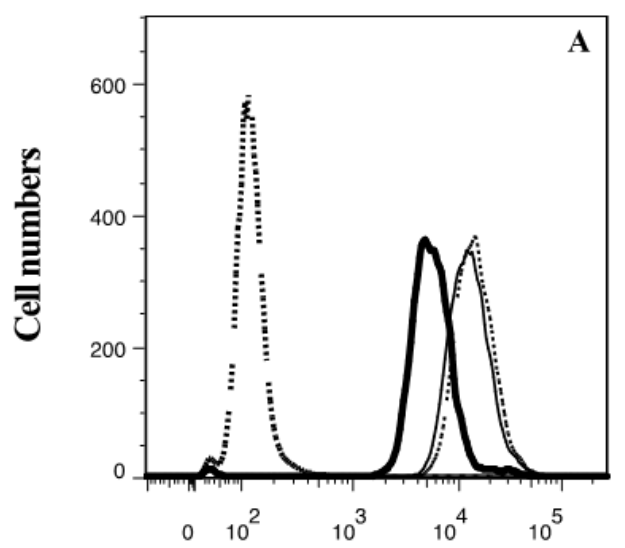

Fluorescent intensity

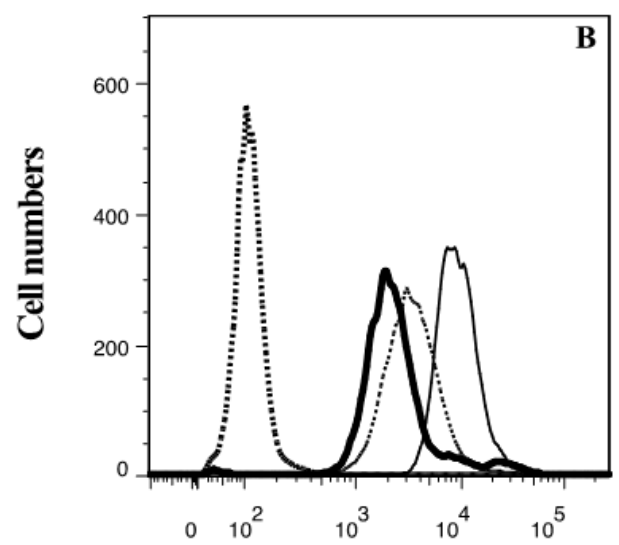

Fluorescent intensity

\subsection{Lamellarin O (11) as a P-gp Inhibitor in SW620 Ad300 Cells (Hoechst 33342 Accumulation/Efflux)}

To further validate the P-gp inhibitory properties of $\mathbf{1 1}$ we used cell flow cytometry to quantify the accumulation and efflux of Hoechst 33342 from P-gp over-expressing SW620 Ad300 cells (Section 3.4). In the accumulation phase treatment with $11(20 \mu \mathrm{M})$ increased intracellular Hoechst 33342 fluorescence levels (2.5-fold) comparable to that achieved by the positive control verapamil (2.3-fold) (Figure 4A), whereas in the efflux phase treatment with $\mathbf{1 1}$ resulted in an increase in intracellular Hoechst 33342 
fluorescence levels (1.4-fold) below than that achieved by verapamil (3.8-fold increase (Figure 4B). These results are consistent with the Calcein AM accumulation (96-well plate format, Section 2.2) and cell flow cytometry (Section 2.3) results detailed above, and confirm that $\mathbf{1 1}$ is a moderate inhibitor of P-gp mediated efflux.

\subsection{Lamellarin O (11) Reverses P-gp Mediated Doxorubicin Resistance in SW620 Ad300 Cells}

P-gp over-expressing colon cancer SW620 Ad300 cells treated with 5.0, 10 and $15 \mu \mathrm{M}$ aliquots of 11 (Table 1) exhibited 1.5-, 3.1- and 4.8-fold increases in sensitivity towards doxorubicin, a well-known cancer chemotherapeutic and P-gp substrate. By contrast, treatment with $2.5 \mu \mathrm{M}$ verapamil resulted in a 8.8-fold increase in sensitivity. These results are consistent with calcein AM accumulation (Sections 2.2 and 2.3), and Hoechst 33342 accumulation/efflux (Section 2.4) assays, establishing 11 as a moderate P-gp inhibitor capable of reversing P-gp mediated doxorubicin resistance in SW620 Ad300 cells.

Table 1. Effect of lamellarin O (11) on P-gp mediated doxorubicin resistance in SW620 Ad300 cells ${ }^{\text {a }}$.

\begin{tabular}{ccc}
\hline Treatment & IC $_{\mathbf{5 0}}{ }^{\mathbf{a}}(\mathbf{n M})$ & DMF $^{\mathbf{b}}$ \\
\hline doxorubicin & $4440 \pm 210$ & \\
+ lamellarin O (11) $5.0 \mu \mathrm{M}$ & $2910 \pm 350$ & 1.5 \\
+ lamellarin O (11) $10 \mu \mathrm{M}$ & $1430 \pm 160$ & 3.1 \\
+ lamellarin O (11) $15 \mu \mathrm{M}$ & $930 \pm 120$ & 4.8 \\
+ verapamil $2.5 \mu \mathrm{M}$ & $500 \pm 230$ & 8.8 \\
\hline
\end{tabular}

${ }^{a}$ Cell survival was determined by MTT assay (Section 3.5). Data are mean values \pm SEM of at least three independent experiments performed in duplicate; ${ }^{\mathrm{b}} \mathrm{DMF}$ : Dose-modifying factor was the ratio of $\mathrm{IC}_{50}$ value of doxorubicin against SW620 Ad300 without an inhibitor to $\mathrm{IC}_{50}$ value of doxorubicin against SW620 Ad300 with an inhibitor.

\subsection{Lamellarin O (11) Reverses BCRP Mediated Efflux in NCI-H460/MX20 Cells}

The flow cytometry based mitoxantrone efflux assay (Section 3.4) [19] was used to screen the BCRP inhibitory properties of 1-12 against the mitoxantrone resistant human lung cancer NCI-H460/ MX20 cells, with a compound designated an inhibitor if a $20 \mu \mathrm{M}$ treatment increased intracellular mitoxantrone fluorescence $\geq 50 \%$ of that exhibited by a $10 \mu \mathrm{M}$ treatment of the positive control FTC $[21,22]$. While the majority of metabolites tested did not exhibit inhibitory activity against BCRP, the increase in intracellular mitoxantrone exhibited by 11 (3.05-fold, $94.5 \%)$ was comparable to that of FTC (3.17-fold, 100\%), indicating that $\mathbf{1 1}$ was a promising BCRP inhibitor (Table 2). 
Table 2. Effect of 1-12 on BCRP mediated efflux in NCI-H460/MX20 cells.

\begin{tabular}{llc}
\hline \multicolumn{1}{c}{ Treatment } & FAR $^{\mathbf{a}}$ & \% FTC $^{\mathbf{b}}$ \\
\hline lamellarin O (11) & 3.05 & 94.5 \\
ianthellidone A (1) & 0.97 & $<1.00$ \\
ianthellidone B (2) & 1.07 & 3.13 \\
ianthellidone C (3) & 1.12 & 5.60 \\
ianthellidone D (4) & 1.15 & 6.66 \\
ianthellidone E (5) & 1.14 & 6.20 \\
ianthellidone F (6) & 1.21 & 9.79 \\
ianthellidone G (7) & 1.09 & 4.06 \\
ianthellidone H (8) & 1.13 & 6.06 \\
lamellarin O1 (9) & 1.23 & 10.6 \\
lamellarin O2 (10) & 1.11 & 5.13 \\
lamellarin Q (12) & 1.41 & 18.6 \\
PBS & 1.00 & 0.00 \\
FTC 10 $\mu \mathrm{M}$ & 3.17 & 100 \\
\hline
\end{tabular}

${ }^{\mathrm{a}}$ FAR (fluorescence arbitrary ratio) $=$ mitoxantrone fluorescence intensity (geometric mean) in the presence of metabolites from Ianthella sp. (CMB-01245) at $20 \mu \mathrm{M} /$ mitoxantrone fluorescence intensity (geometric mean) in the presence of PBS, expressed as a ratio. Positive control is FTC at $10 \mu \mathrm{M}$ which FAR $=3.17$; ${ }^{\mathrm{b}}$ activities for inhibition on mitoxantrone efflux were normalized to $10 \mu \mathrm{M}$ FTC response according to the following equation: $\% \mathrm{FTC}=(\mathrm{RFU}$ test sample $-\mathrm{RFU}$ negative $) /\left(\mathrm{RFU}_{\mathrm{FTC}}-\mathrm{RFU} \mathrm{negative}\right) \times 100 \%$; $\mathrm{RFU}$ test sample is relative intracellular mitoxantrone fluorescent unit (geometric mean) in the presence of compound $(20 \mu \mathrm{M})$, RFU FTC is relative intracellular mitoxantrone fluorescent unit (geometric mean) in the presence of $10 \mu \mathrm{M}$ FTC (positive control) and RFU negative is relative intracellular mitoxantrone fluorescent unit (geometric mean) in the absence of sample (PBS only). A sample was determined to inhibit BCRP when \% maximum was $>50 \%[21,22]$.

\subsection{Lamellarin O (11) Reverses Efflux of [ $\left.{ }^{3} H\right]$-Mitoxantrone in NCI-H460/MX20 Cells}

The BCRP inhibitory activity exhibited by $\mathbf{1 1}$ was further verified by evaluating its effect on the intracellular accumulation and efflux of $\left[{ }^{3} \mathrm{H}\right]$-mitoxantrone. Briefly, in accumulation phase, parental cells (NCI-H460) and BCRP over-expressing daughter cells (NCI-H460/MX20) were cultured with $\left[{ }^{3} \mathrm{H}\right]$-mitoxantrone $(0.10 \mu \mathrm{M})$ in the presence or absence of FTC $(5.0 \mu \mathrm{M})$, or $11(10$ or $30 \mu \mathrm{M})$. After $1 \mathrm{~h}$ incubation, the intracellular $\left[{ }^{3} \mathrm{H}\right]$-mitoxantrone was measured using a liquid scintillation analyzer, quantifying the ability of $\mathbf{1 1}$ to increase the uptake of the BCRP substrate $\left[{ }^{3} \mathrm{H}\right]$-mitoxantrone. In the efflux phase, cells from the accumulation phase were washed to remove extracellular $\left[{ }^{3} \mathrm{H}\right]$-mitoxantrone and incubated with additional FTC $(5.0 \mu \mathrm{M})$, or $11(10$ or $30 \mu \mathrm{M})$ in media without $\left[{ }^{3} \mathrm{H}\right]$-mitoxantrone. By measuring intracellular and media levels of $\left[{ }^{3} \mathrm{H}\right]$-mitoxantrone it was possible to quantify the effect of FTC and $\mathbf{1 1}$ on BCRP mediated efflux of a $\left[{ }^{3} \mathrm{H}\right]$-mitoxantrone.

In the accumulation phase neither $11(10$ or $30 \mu \mathrm{M})$ nor FTC $(5.0 \mu \mathrm{M})$ significantly changed intracellular $\left[{ }^{3} \mathrm{H}\right]$-mitoxantrone levels in NCI-H460 cells, however, by contrast $\mathbf{1 1}$ increased $\left[{ }^{3} \mathrm{H}\right]$-mitoxantrone accumulation in NCI-H460/MX20 cells (1.3- and 2.3-fold by 10 and $30 \mu \mathrm{M}$, respectively) comparable to the increase observed for FTC (2.2-fold) (Figure 5). 
Figure 5. Effect of $\mathbf{1 1}$ on the accumulation of $\left[{ }^{3} \mathrm{H}\right]$-mitoxantrone. The accumulation of $\left[{ }^{3} \mathrm{H}\right]$-mitoxantrone in parental NCI-H460 cells and in BCRP over-expressing NCI-H460/ MX20 cells was measured (Section 3.6). Columns are the mean of triplicate determinations. Error bars represent the $\mathrm{SD} ; * p<0.05 v s$. the control group. Experiments were performed in three independent times, and a representative experiment is shown.

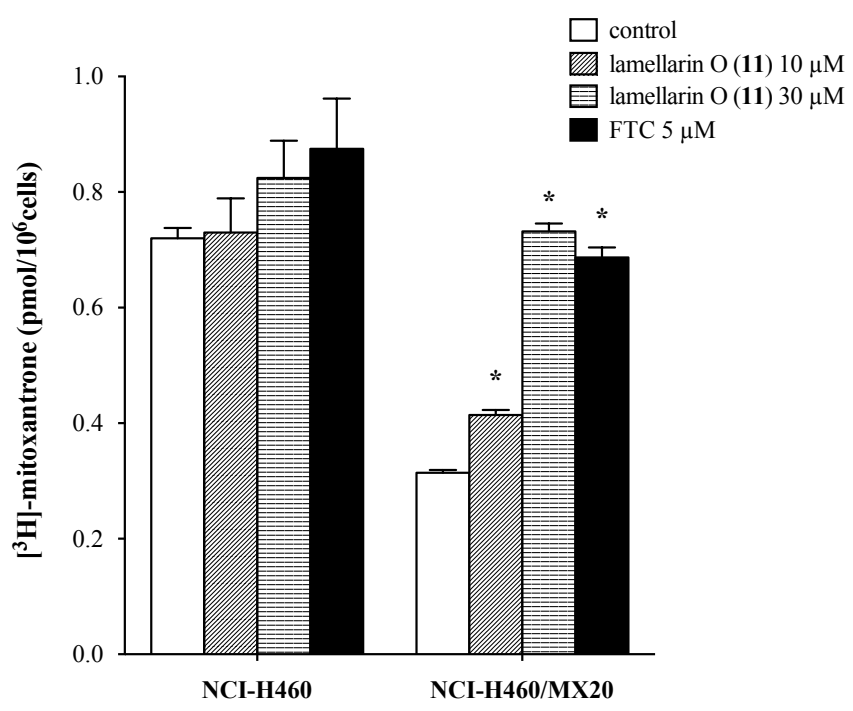

In the efflux phase the intracellular level of $\left[{ }^{3} \mathrm{H}\right]$-mitoxantrone in BCRP over-expressing NCI-H460/ MX20 cells (Figure 6B) was significantly less than that in parental cells (Figure 6A), however, when treated with $11(10$ and $30 \mu \mathrm{M})$ NCI-H460/MX20 cells displayed a concentration dependent increase in intracellular $\left[{ }^{3} \mathrm{H}\right]$-mitoxantrone levels, comparable with treatment with FTC $(5.0 \mu \mathrm{M})$. Neither 11 nor FTC had a significant effect on the intracellular levels of $\left[{ }^{3} \mathrm{H}\right]$-mitoxantrone in parental cells (Figure 6). This study indicates that $\mathbf{1 1}$ is a promising BCRP inhibitor, with the potential to increase uptake and decrease efflux of cancer chemotherapeutics in BCRP over-expressing cells.

Figure 6. Effect of $\mathbf{1 1}$ on the efflux of $\left[{ }^{3} \mathrm{H}\right]$-mitoxantrone in (A) NCI-H460 cells and (B) NCI-H460/MX20 cells. A time course $v s$. \% of intracellular $\left[{ }^{3} \mathrm{H}\right]$-mitoxantrone remaining was plotted; $* p<0.05$ vs. control group. Error bars represent the SD. Experiments were carried out in triplicate.

\section{A}

B
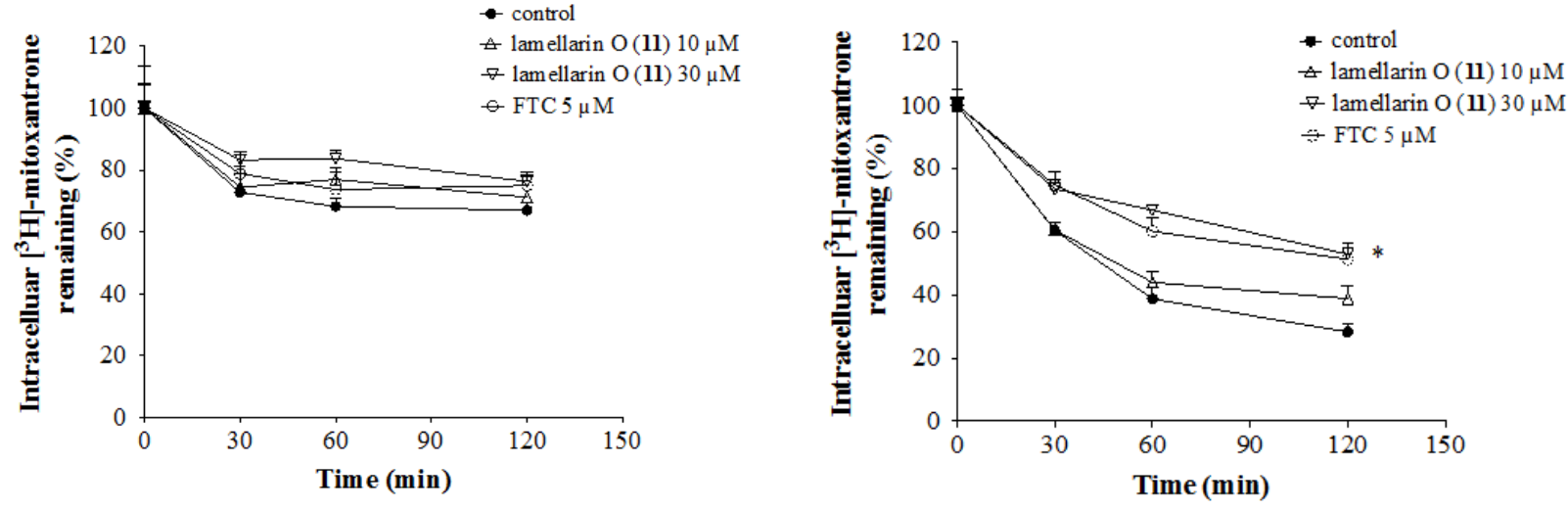


\subsection{Effect of Lamellarin O (11) on BCRP Expression in NCI-H460/MX20 Cells}

In addition to possibly acting as a small molecule inhibitor of BCRP functionality, an alternative mechanism by which 11 may decrease BCRP mediated cellular efflux of $\left[{ }^{3} \mathrm{H}\right]$-mitoxantrone is via decreasing cellular levels of BCRP. In order to test this alternative mechanism we incubated NCI-H460 MX20 cancer cells in the absence $(0 \mathrm{~h})$ and in the presence of $30 \mu \mathrm{M} 11$ (24, 48 and $72 \mathrm{~h})$, and determined BCRP expression using Western blotting analysis. As illustrated (Figure 7A) BCRP was expressed significantly in NCI-H460/MX20 cells, but slightly in NCI-H460 cells. The BCRP levels in NCI-H460/MX20 cells were not significantly changed after 24, 48 or 78 h (Figure 7B,C), confirming that $\mathbf{1 1}$ does not alter BCRP expression.

Figure 7. Western blotting analysis of BCRP and effect of 11 on BCRP expression in NCI-H460/MX20 cells. (A) Expression of BCRP in NCI-H460 and NCI- H460/MX20 cells; (B) Effect of $11(30 \mu \mathrm{M})$ on expression level of BCRP in NCI-H460/MX20 cells $(0,24,48$ and $72 \mathrm{~h})$; (C) Quantitative analysis on relative expression levels of ABCG2. Columns are grayscale ratios of BCRP over $\beta$-actin. Error bars represent SD. Equal amounts of total cell lysate were used for each Western blotting (Section 3.7). Representative results are shown, with similar results obtained in two other trials.

A

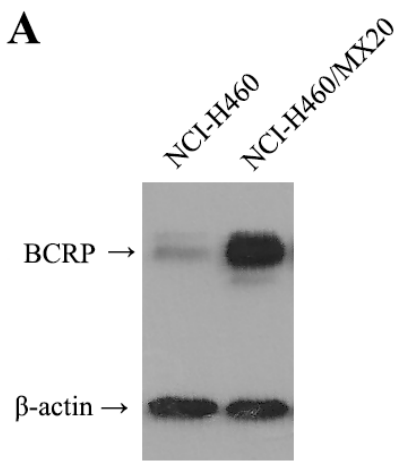

B
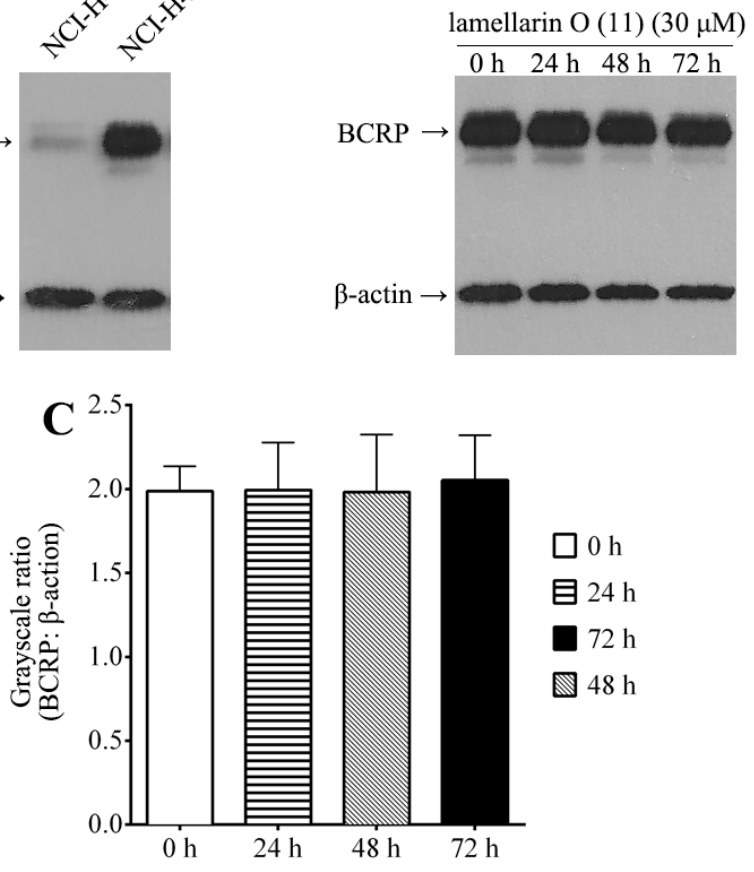

\subsection{Structure Activity Relationship (SAR) Studies on Lamellarin O (11)}

The results as outlined above established $\mathbf{1 1}$ as a significantly more potent BCRP inhibitor than the biosynthetically related co-metabolites $\mathbf{1 - 1 0}$ and $\mathbf{1 2}$, indicative of a structure-activity relationship (SAR) in which the methoxy-acetophenone moiety (highlighted in Figure 8) may be a critical determinant. In light of this we reasoned that further SAR studies, including an evaluation of methylated analogues incorporating the core methoxy-acetophenone moiety, would be highly informative. To support SAR 
studies we sourced the synthetic analogues 13-16 from an in-house compound library, and prepared the mono and dimethyl analogues 17-19. All these analogues incorporate the methoxy-acetophenone moiety unique to 11, but absent from the closely related and BCRP inactive 9-10.

Figure 8. SAR studies on lamellarin O (11) with the methoxy-acetophenone moiety highlighted.

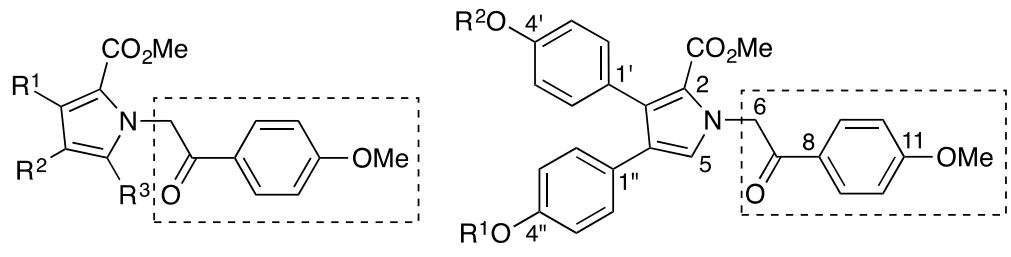
(13) $R^{1-3}=H$
(14) $\mathrm{R}^{1,3}=\mathrm{H}, \mathrm{R}^{2}=\mathrm{Br}$
(11) $\mathrm{R}^{1-2}=\mathrm{H}$
(17) $\mathrm{R}^{1}=\mathrm{Me}, \mathrm{R}^{2}=\mathrm{H}$
(15) $R^{1-2}=H, R^{3}=B r$
(16) $\mathrm{R}^{1-3}=\mathrm{Br}$
(18) $R^{1}=H, R^{2}=M e$
(19) $\mathrm{R}^{1-2}=\mathrm{Me}$<smiles>CC(=O)c1c(-c2ccc(O)cc2)c(-c2ccc(O)cc2)cn1CC(=O)c1ccc(O)cc1</smiles>

(9)<smiles>CC(=O)c1c(-c2ccc(O)cc2)c(-c2ccc(O)cc2)cn1CC(O)c1ccc(O)cc1</smiles>

(10)

Evaluation of 13-16 using the flow cytometry based mitoxantrone efflux assay (Section 3.4) showed that none of these compounds inhibited BCRP $(<10 \%$ of $10 \mu \mathrm{M}$ FTC, Supplementary Table S3). The BCRP inhibitory properties of $\mathbf{1 7}+\mathbf{1 8}$ (mixture) and 19 were also evaluated over a range of concentrations $(0.1$ to $100 \mu \mathrm{M})$, and compared to 11 , using the flow cytometry based mitoxantrone efflux assay (Table 3, Figure 9). This analysis confirmed the $\mathrm{IC}_{50}$ and maximal responses (\%FTC) for $11(4.7 \mu \mathrm{M}$ and $113 \%)$ were far superior to those for $\mathbf{1 7}+\mathbf{1 8}(20 \mu \mathrm{M}$ and $66 \%)$ and $19(100 \mu \mathrm{M}$ and $46 \%)$.

Table 3. The effect of lamellarin O (11) and methylated derivatives 17-19 on BCRP mediated efflux of mitoxantrone in BCRP over-expressing NCI-H460/MX20 cells.

\begin{tabular}{ccc}
\hline & IC $_{\mathbf{5 0}}(\boldsymbol{\mu M})^{\text {a }}$ & Maximal Activity (\% of FTC) \\
\hline $\mathbf{1 1}$ & $4.7 \pm 0.6$ & 112.9 \\
$\mathbf{1 7}+\mathbf{1 8}$ & $20.2 \pm 2.1$ & 65.7 \\
$\mathbf{1 9}$ & $>100$ & 45.4 \\
\hline${ }^{\mathrm{a}} \mathrm{IC}_{50}$ values were calculated from dose-response data using Prism analysis.
\end{tabular}

While limited, these SAR results nevertheless confirm that replacing the phenyl substituents pendant to the pyrrole moiety in 11 with bromo groups (e.g., 13-16), or mono/di methylation of phenolic moieties (e.g., 17-19), leads to a significant reduction in BCRP inhibitory activity. From this we conclude that while the methoxy-acetophenone moiety in $\mathbf{1 1}$ appears essential to delivering BCRP inhibitory activity, as seen by the loss of activity in $\mathbf{9 - 1 0}$, by itself this moiety is not sufficient to deliver a BCRP inhibitory effect. 
Figure 9. Effect of 11 and its methylated derivatives 17-19 on the BCRP mediated efflux of mitoxantrone in BCRP over-expressing NCI-H460/MX20 cells. NCI-H460/MX20 cells were incubated with mitoxantrone in the absence or presence of 11 , mix of $17+18$, or 19 $(0.1$ to $100 \mu \mathrm{M})$, or the positive control FTC $(10 \mu \mathrm{M})$, after which the cells were washed twice with ice-cold PBS, and incubated without or with test compounds for a further $1 \mathrm{~h}$ in mitoxantrone free medium. Mitoxantrone fluorescence was detected with a 638-nm argon laser and a 660/20 nm band-pass filter. Data were collected by cell flow cytometry according (Section 3.4) and normalized to that obtained with $10 \mu \mathrm{M}$ FTC (signal set as 100\%). Data are means $\pm \mathrm{SEM}$ of at least three independent experiments performed in duplicate.

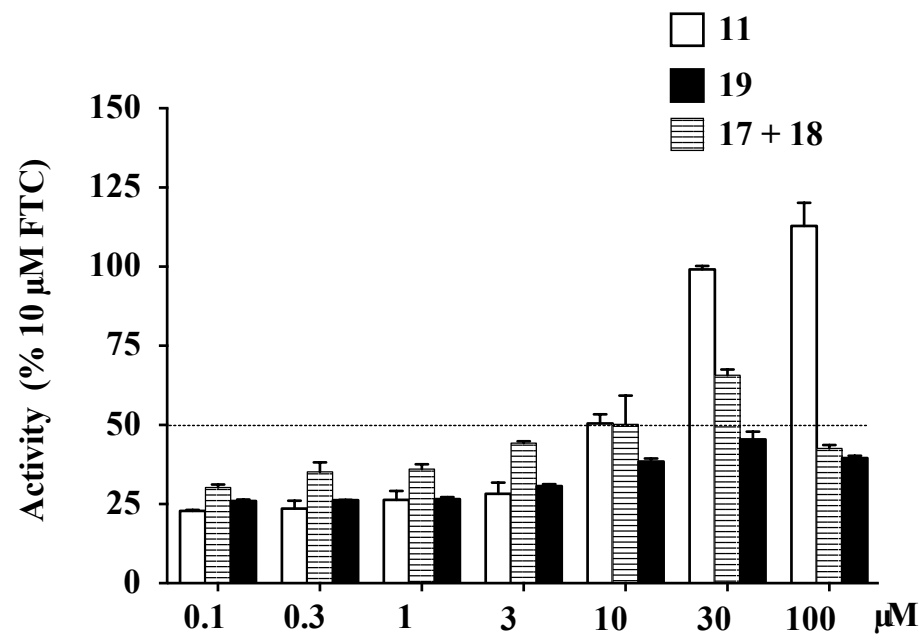

\subsection{Docking Analysis of Lamellarin O (11) and 19 with Human ABCG2 Homology Models}

To support SAR analyses we compared docking studies on the BCRP inhibitor 11, with those on the BCRP inactive analogue 19. In these studies, docking of $\mathbf{1 1}$ into the large drug-binding cavity of human ABCG2 revealed hydrogen bonding between the two phenolic residues, and Arg482

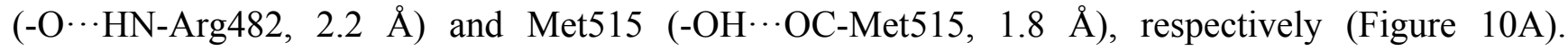
Similarly, the ester and methoxy-acetophenone moieties were seen to engage in hydrogen bonding

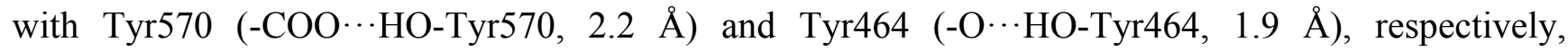
while 11 was further stabilized in the hydrophobic pocket by several hydrophobic and aromatic interactions. Importantly, hydrogen bonding to the phenol residues provides an insight into the likely mechanism behind the loss of BCRP inhibitory activity observed in the dimethylated analogue 19 as shown in Figure 10B.

\subsection{The Effect of Lamellarin O (11) on the MRP1 Mediated Efflux of Calcein in 2008/MRP1 Cells}

Inspired by its P-gp and BCRP inhibitory properties, we used the Calcein AM assay supported by cell flow cytometry (Sections 3.3 and 3.4) to examine the effect of $\mathbf{1 1}$ on the MRP1 mediated efflux of calcein AM. Treatment of 2008/MRP1 cells with $20 \mu \mathrm{M}$ of $\mathbf{1 1}$ revealed only a modest increase in intracellular calcein fluorescence (1.4-fold), below than that exhibited by treatment with $50 \mu \mathrm{M}$ of the positive control MK571 (3.2-fold), confirming that $\mathbf{1 1}$ is a weak inhibitor of MRP1 (Figure 11). 
Figure 10. XP-Glide predicted binding mode of lamellarin O (11) with homology modeled ABCG2. (A) Binding mode of $\mathbf{1 1}$ within the drug binding site-1 of human ABCG2. Important residues are depicted as sticks with the atoms colored as carbon-gray, hydrogen-white, nitrogen-blue, oxygen-red, sulfur-yellow whereas $\mathbf{1 1}$ is shown as ball and stick model with the same color scheme as above except carbon atoms are represented in orange. Dotted black lines indicate proposed hydrogen bonds; (B) Compound 19 within the drug binding site-1 of human ABCG2.
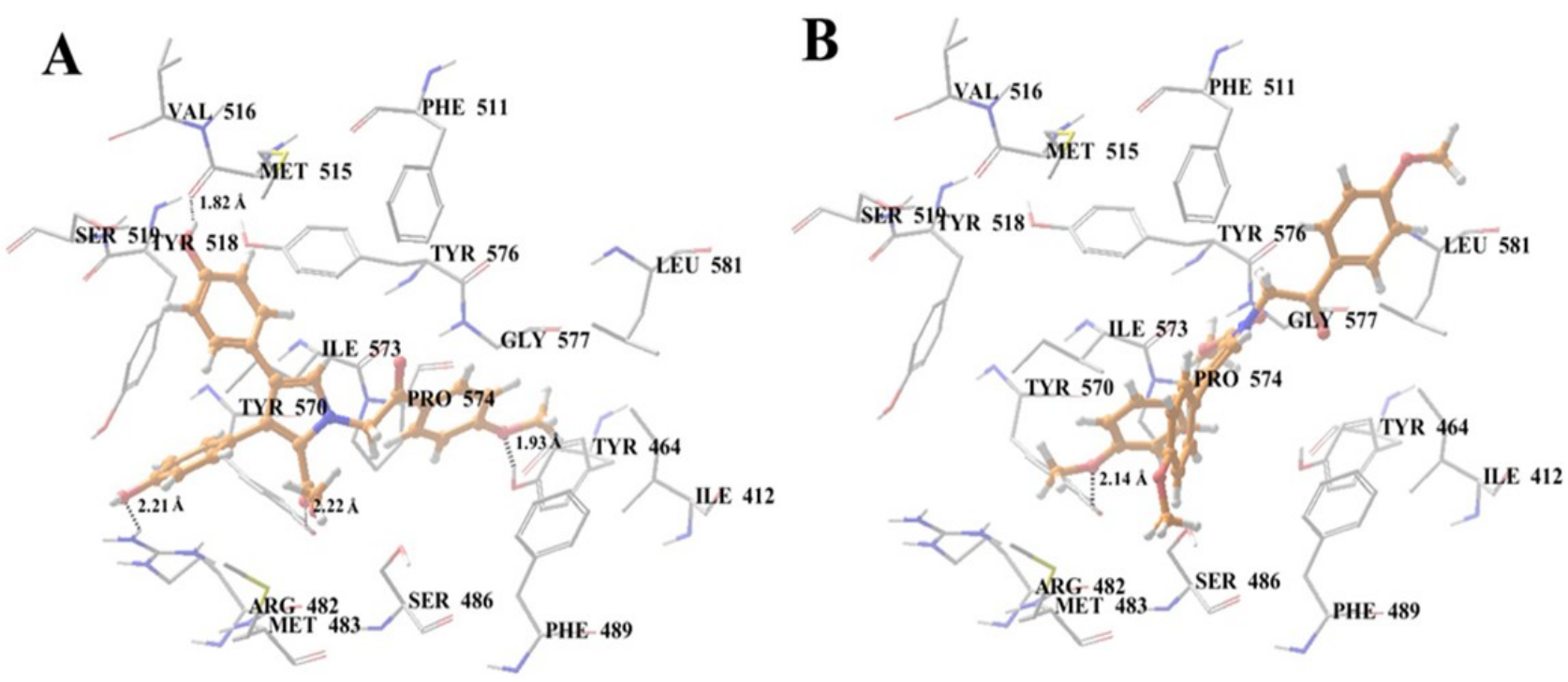

Figure 11. Effect of lamellarin O (11) on the efflux of MRP1 fluorescent substrate calcein in MRP1 over-expressing 2008/MRP1 cells. Cells were incubated for 30 min with calcein $\mathrm{AM}$ in the absence (heavy solid line) or presence (dashed line) of $11(20 \mu \mathrm{M})$, or the positive control MK571 (50 $\mu \mathrm{M})$ (thin solid light). Subsequently, cells were washed twice with ice-cold PBS and incubated without or with compounds for $1 \mathrm{~h}$ in calcein AM-free medium. Intracellular fluorescence of calcein was detected with a $488 \mathrm{~nm}$ argon laser and a $530 / 30 \mathrm{~nm}$ band pass filter. Data were analyzed by flow cytometry according (Section 3.4). Representative results from at least two independent experiments were shown.

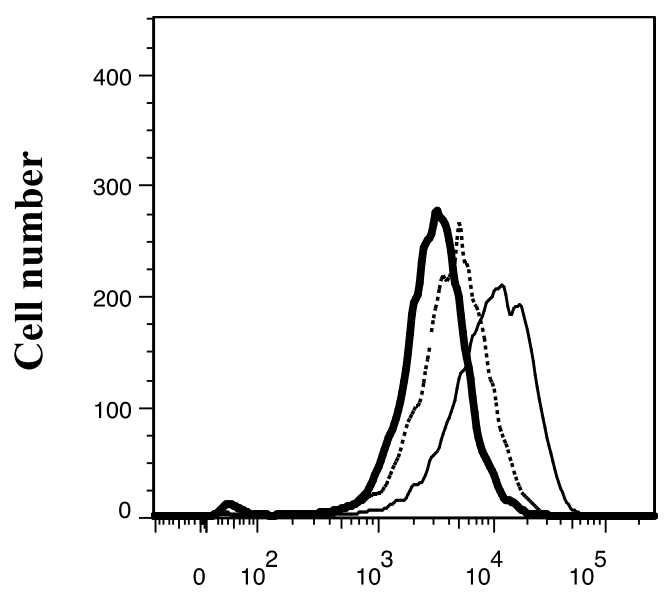

Fluorescence intensity 


\section{Experimental Section}

\subsection{Chemical Materials}

Doxorubicin was a gift from BioAustralis Fine Chemicals (Smithfield, NSW, Australia). MK571 was purchased from Cayman Chemical Company (Ann Arbor, MI, USA). Fumitremorgin C (FTC), originally prepared by Thomas McCloud (Developmental Therapeutics Program, Natural Products Extraction Laboratory, NIH, Bethesda, MD, USA), was provided by Susan E. Bates and Robert W. Robey. $\left[{ }^{3} \mathrm{H}\right]$-mitoxantrone $(2.5 \mathrm{Ci} / \mathrm{mmol})$ was supplied from Moravek Biochemicals Inc. (Brea, CA, USA). Monoclonal antibody BXP-21 (against ABCG2) was purchased from Signet Laboratories Inc. (Dedham, MA, USA). Calcein AM and Hoechst 33342 were purchased from Enzo Life Inc. (Plymouth Meeting, PA, USA). Dimethylsulfoxide (DMSO) was acquired from Chem-Supply Pty. Ltd. (Gillman, SA, Australia). G418 was supplied from Invitrogen (Carlsbad, CA, USA). Pheophorbide A (PhA) was purchased from Frontier Scientific, Inc. (Logan, UT, USA). 3-(4,5-dimethylthiazol-2-yl)-2,5-diphenyltetrazolium bromide (MTT), mitoxantrone, verapamil, propidium iodide, and other chemicals were obtained from Sigma-Aldrich Pty. Ltd. (Castle Hill, NSW, Australia).

The marine natural products 1-12, reported in 2012 by Zhang et al. [23] from a southern Australian marine sponge, Ianthella sp. (CMB-01245), and the structurally related synthetic compounds 13-16 were available from one of the authors (Robert J. Capon). The analogues 17-19 were prepared from the natural product 11 as described below. All compounds (1-19) were subjected to HPLC-DAD-MS and ${ }^{1} \mathrm{H}$ NMR analysis prior to detailed biological experiments.

\subsection{Cell Lines and Cell Culture}

Three human cancer cell lines (SW620, NCI-H460 and 2008) and their ABC transporter over-expressing counterparts (SW620 Ad300, NCI-H460/MX20 and 2008/MRP1) were examined in this study. The drug-resistant P-gp over-expressing daughter cell line SW620 Ad300 was established by stepwise selection of the parental human colon cancer cell line SW620 in increasing concentrations of doxorubicin, and was maintained in RPMI1640 (Invitrogen, Carlsbad, CA, USA) containing doxorubicin $(300 \mathrm{ng} / \mathrm{mL})$. The drug-resistant BCRP over-expressing daughter cell line NCI-H460/MX20 was established by stepwise selection of the parental human non-small cell lung cancer cell NCI-H460 in increasing concentrations of mitoxantrone, and was maintained in RPMI1640 containing mitoxantrone $(20 \mathrm{nM})$. These four cell lines were kindly provided by Susan E. Bates and Robert W. Robey of the National Cancer Institute, Bethesda, MD, USA [24]. In order to confirm their drug resistance characteristics, the drug-selected MDR cell lines (SW620 Ad300 and NCI-H460/MX20 were transferred to drug-free medium until two weeks before assays. The human ovarian carcinoma cell line 2008 and its ABCC1 transduced sub-line 2008/MRP1 [25] were generously provided by Johan Allen (The University of Sydney) with permission from Piet Borst (the National Cancer Institute, Amsterdam, The Netherlands). All cell lines were grown in flasks in a humidified incubator at $37{ }^{\circ} \mathrm{C}$ with $5 \% \mathrm{CO}_{2}$ with RPMI 1640, which was supplemented with $10 \%$ fetal bovine serum, L-glutamine $(2 \mathrm{mM})$, penicillin (100 unit $/ \mathrm{mL})$ and streptomycin $(100 \mu \mathrm{g} / \mathrm{mL})$ (Invitrogen, Carlsbad, CA, USA). 


\subsection{Calcein AM Accumulation Assay (96-Well Plate Format)}

The Calcein AM accumulation assay (96-well plate format) was modified based on the original method [26]. The non-fluorescent reagent calcein AM can diffuse into the cellular cytoplasm and yield the fluorescent dye calcein after hydrolysis by intracellular esterases. As calcein AM is a P-gp substrate, in the presence of functioning P-gp it is largely effluxed prior to hydrolysis, resulting in low levels of intracellular fluorescence. A P-gp inhibitor can block the efflux of calein AM, which then undergoes hydrolysis to calcein which is not a P-gp substrate, leading to higher levels of intracellular fluorescence. Briefly, after harvesting with trypsin, $5 \times 10^{4}$ SW620 Ad300 cells (in $100 \mu \mathrm{L}$ ) were seeded into a well of 96-well flat clear-bottom black-wall microtitre plates (AP, Falcon, 353219, BD, Franklin Lakes, NJ, USA). Following $48 \mathrm{~h}$ incubation at $37{ }^{\circ} \mathrm{C}$ with $5 \% \mathrm{CO}_{2}$, wells were treated with an aliquot $(25 \mu \mathrm{L})$ of test compounds $(20 \mu \mathrm{M})$, or verapamil $(100 \mu \mathrm{M}$ as a positive control), or $1 \%$ DMSO in PBS (v/v, negative control), for 15 min at $37{ }^{\circ} \mathrm{C}$ with $5 \% \mathrm{CO}_{2}$. An aliquot $(25 \mu \mathrm{L})$ of calcein AM $(0.25 \mu \mathrm{M})$ was then added to each well, except for background control wells, which were treated with a $25 \mu \mathrm{L}$ PBS. Plates were incubated at $37{ }^{\circ} \mathrm{C}$ with $5 \% \mathrm{CO}_{2}$ for a further $30 \mathrm{~min}$, after which intracellular calcein fluorescent intensity (arbitrary unit) was measured by a POLARstar Omega plate reader (BMG LABTECH, Offenburg, Germany) at $490 \mathrm{~nm}$ (excitation wavelength) and $510 \mathrm{~nm}$ (emission wavelength). Data (fluorescence unit, FU) were normalized to verapamil treated cells on the same microtitre plate, and reported as $\%$ of $100 \mu \mathrm{M}$ verapamil activity according to:

$$
\% \text { maximum }=\left(\mathrm{FU}_{\text {sample }}-\mathrm{FU}_{\text {negative }}\right) /\left(\mathrm{FU}_{\text {verapamil }}-\mathrm{FU}_{\text {negative }}\right) \times 100
$$

where $\mathrm{FU}_{\text {sample }}$ is fluorescence in the presence of test compounds $(20 \mu \mathrm{M}), \mathrm{FU}_{\text {verapamil }}$ is fluorescence in the presence of verapamil $(100 \mu \mathrm{M})$ and $\mathrm{FU}_{\text {negative }}$ is fluorescence in the absence of sample (negative control). A sample with P-gp inhibitory activity was determined when $\%$ maximum was $>30 \%$. All experiments were performed in duplicate.

\subsection{Flow Cytometry Assays}

Flow cytometry based assays were used to measure the ability of natural or synthetic compounds to inhibit P-gp, BCRP or MRP1 mediated accumulation and/or efflux of fluorescent reagents [21]. Briefly, SW620 Ad300 cells (P-gp over-expressing), NCI-H460/MX20 cells (BCRP over-expressing), or 2008/MRP1 cells (MRP1 over-expressing), were harvested with trypsin and re-suspended in phenol red-free RPMI 1640 (with 10\% FBS) to give a final concentration of $50 \times 10^{4}$ cells $/ \mathrm{mL}$. Cells were then pre-incubated with $20 \mu \mathrm{M}$ of test compounds, or $20 \mu \mathrm{M}$ of verapamil (positive control for P-gp), or $10 \mu \mathrm{M}$ FTC (positive control for BCRP) or $50 \mu \mathrm{M}$ MK571 (positive control for MRP1) for $15 \mathrm{~min}$ at $37{ }^{\circ} \mathrm{C}$ in $5 \% \mathrm{CO}_{2}$. For the comparison of BCRP inhibitory activity of lamellarin $\mathrm{O}(\mathbf{1 1})$ and its permethylated derivatives (mix of 17+18, or 19), NCI-H460/MX20 cells were treated with compounds at a series of concentration $(0.1,0.3,1,3,10,30$ and $100 \mu \mathrm{M})$. Subsequently, cells were incubated with reagents $(0.25 \mu \mathrm{M}$ calcein AM or $60 \mu \mathrm{M}$ Hoechst 33342 for P-gp, $20 \mu \mathrm{M}$ of mitoxantrone for BCRP, and $0.25 \mu \mathrm{M}$ calcein AM for MRP1) for 30 min followed by washing twice with cold medium. For the calcein AM accumulation assays, cells were directly analyzed by flow cytometry. For the efflux assays, cells treated with Hoechst 33342 (P-gp), mitoxantrone (BCRP) or calcein AM (MRP1) were 
incubated for $1 \mathrm{~h}$ in fluorescence reagent free medium with or without compounds, or corresponding positive controls (see above), after which cells were washed twice with cold medium.

Intracellular fluorescence intensity was measured on a BD FACSCanto ${ }^{\mathrm{TM}}$ II flow cytometer (Becton Dickinson, San Jose, CA, USA) and data were analyzed through FlowJo (Tree Star, Inc., Ashland, OR, USA). Calcein was detected with a $480 \mathrm{~nm}$ laser and a 530/30 nm band-pass filter, whereas Hoechst 33342 was detected using a $405 \mathrm{~nm}$ laser and a 450/50 nm band-pass filter. Mitoxantrone fluorescence was detected with a $638 \mathrm{~nm}$ argon laser and a 660/20 nm band-pass filter. At least 10,000 events were collected for all of the flow cytometry experiment. By increasing threshold value on forward scatter versus side scatter, debris was eliminated. Dead cells were excluded based on propidium iodide staining. Data are means \pm SEM of at least three independent experiments performed in duplicate.

\subsection{MTT Cytotoxicity Assay}

The MTT assay was modified based on that previously described [27], using adherent cell lines SW620 and NCI-H460, and their P-gp over-expressing daughter cell line SW620 Ad300 and BCRP over-expressing daughter cell line NCI-H460/MX20, respectively. Briefly, cells were harvested with trypsin and added into 96-well microtitre assay plates at 2000 cells/well, followed by $18 \mathrm{~h}$ incubation at $37{ }^{\circ} \mathrm{C}$ with $5 \% \mathrm{CO}_{2}$. Lamellarin $\mathrm{O}(11)$ was dissolved in $5 \%$ DMSO in PBS $(v / v)$ and aliquots $(20 \mu \mathrm{L})$ tested over a series of concentrations. Control wells were treated with 5\% aqueous DMSO. When the assay was used for P-gp MDR reversal activity, SW620 Ad300 cells were co-incubated with 5,10 or $15 \mu \mathrm{M}$ aliquots of lamellarin $\mathrm{O}(\mathbf{1 1})$, or $2.5 \mu \mathrm{M}$ verapamil, together with doxorubicin at a series of concentrations. $68 \mathrm{~h}$ later, $20 \mu \mathrm{L}$ MTT ( $4 \mathrm{mg} / \mathrm{mL}$ in PBS) was dispensed into each well (final concentration $0.40 \mathrm{mg} / \mathrm{mL}$ ), and plates were incubated for a further $4 \mathrm{~h}$ at $37{ }^{\circ} \mathrm{C}$ with $5 \% \mathrm{CO}_{2}$. Finally medium was removed and precipitated formazan crystals were dissolved in $100 \%$ DMSO. The absorbance of each well was measured at $580 \mathrm{~nm}$ with a PowerWave XS Microplate Reader from Bio-Tek Instruments Inc. (Vinooski, VT, USA).

$\mathrm{IC}_{50}$ values were calculated using Prism 5.0 (GraphPad Software Inc., La Jolla, CA, USA), as the concentration of analyte required for $50 \%$ inhibition of cancer cell growth (compared to negative controls). All experiments were performed in duplicate.

\subsection{Drug Accumulation and Efflux Assay}

The effect of lamellarin $O$ (11) on the intracellular accumulation of mitoxantrone in BCRP over-expressing cells was determined by measuring the intracellular accumulation of $\left[{ }^{3} \mathrm{H}\right]$-mitoxantrone in NCI-H460 and NCI-H460/MX20 cells. Cells were trypsinized and three aliquots $\left(5 \times 10^{6}\right.$ cells $)$ from each cell line were resuspended in medium and pre-incubated for $1 \mathrm{~h}$ at $37^{\circ} \mathrm{C}$ with or without 10 or $30 \mu \mathrm{M}$ lamellarin $\mathrm{O}(\mathbf{1 1})$, or $5 \mu \mathrm{M}$ FTC. To measure drug accumulation, cells were subsequently incubated for $2 \mathrm{~h}$ at $37{ }^{\circ} \mathrm{C}$ with $5 \% \mathrm{CO}_{2}$ with $0.1 \mu \mathrm{M}\left[{ }^{3} \mathrm{H}\right]$-mitoxantrone in RPMI 1640 medium, in the presence or absence of $10,30 \mu \mathrm{M}$ lamellarin O (11), or $5 \mu \mathrm{M}$ FTC. The resulting cells were pelleted at $4{ }^{\circ} \mathrm{C}$, washed three times with $10 \mathrm{~mL}$ ice-cold PBS, placed in lysis buffer, and radioactivity measured using a Packard TRI-CARB 1900CA liquid scintillation analyzer from Packard Instrument Company Inc. (Downers Grove, IL, USA) as previously described [28]. 
In the efflux study cells were incubated with $0.1 \mu \mathrm{M}\left[{ }^{3} \mathrm{H}\right]$-mitoxantrone as the same in the accumulation study. After washing three times with cold PBS, the suspended cells were incubated at $37{ }^{\circ} \mathrm{C}$ in fresh medium in the presence or absence of 10 or $30 \mu \mathrm{M}$ lamellarin $\mathrm{O}(\mathbf{1 1})$, or $5 \mu \mathrm{M}$ FTC. After $0,30,60$, and 120 min aliquots of cells were removed and immediately washed three times with $10 \mathrm{~mL}$ of ice-cold PBS. The resulting cells were pelleted and processed for measurement of radioactivity (as indicated above).

\subsection{Preparation of Total Cell Lysates and Western Blotting}

Cells were treated with $30 \mu \mathrm{M}$ lamellarin O (11) for $0,24,48$ and $72 \mathrm{~h}$, after which cell lysates were prepared as previously described [28] and stored at $-80{ }^{\circ} \mathrm{C}$ until the gel electrophoresis was run. Protein concentrations were determined by bicinchonic acid $\left(\mathrm{BCA}^{\mathrm{TM}}\right)$ based protein assay (Thermo Scientific, Rockford, IL, USA). Equal amounts of total cell lysates (20 $\mu$ g protein) were resolved by SDS-PAGE and electrophoretically transferred onto PVDF membranes. Following $1 \mathrm{~h}$ incubation in a blocking solution in TBST buffer at room temperature, the membranes were immunoblotted for $2 \mathrm{~h}$ at room temperature with primary monoclonal antibodies against actin, at a 1:400 dilution, or ABCG2, at a 1:100 dilution. The membranes were then further incubated for $1 \mathrm{~h}$ at room temperature with HRP-conjugated secondary antibody (1:2000 dilution). Finally the protein-antibody complex was detected by enhanced chemiluminescence detection system (Amersham, NJ, USA). In addition, levels of protein expression were quantified by ImageJ Software (NIH, Bethesda, MD, USA).

\subsection{Syntheses of Methylated Lamellarin O Derivatives $(17,18$ and 19)}

A solution of $11(7.7 \mathrm{mg}, 0.017 \mathrm{mmol})$ in acetone $(2 \mathrm{~mL})$ was treated with a 3-fold excess of MeI (7.2 $\mathrm{mg}, 0.051 \mathrm{mmol})$, and $\mathrm{K}_{2} \mathrm{CO}_{3}(14.0 \mathrm{mg}, 0.10 \mathrm{mmol})$, and was stirred at ambient temperature overnight. After filtration the eluent was concentrated in vacuo and the residue purified by semi-preparative HPLC (Agilent Zorbax Rx-C $8,5 \mu \mathrm{m}, 9.4 \times 250 \mathrm{~mm}$ column, $15 \mathrm{~min}$ gradient elution at $3.5 \mathrm{~mL} / \mathrm{min}$ from $90 \% \mathrm{H}_{2} \mathrm{O} / \mathrm{MeCN}$ to $100 \% \mathrm{MeCN}$ with an isocratic $0.01 \% \mathrm{TFA} / \mathrm{H}_{2} \mathrm{O}$ modifier) to afford 4'-methyl-lamellarin $\left.\mathrm{O}(\mathbf{1 8}) ; t_{\mathrm{R}} 13.52 \mathrm{~min}, 3.9 \mathrm{mg}, 50 \%\right)$, 4"-methyl-lamellarin $\mathrm{O}$ (17); $\left.t_{\mathrm{R}} 13.7 \mathrm{~min}, 2.4 \mathrm{mg}, 30 \%\right)$ and $4^{\prime}, 4^{\prime \prime}$-dimethyl-lamellarin $\left.\mathrm{O}(\mathbf{1 9}) ; t_{\mathrm{R}} 15.4 \mathrm{~min}, 0.6 \mathrm{mg}, 8.0 \%\right)$.

A solution of $11(3 \mathrm{mg}, 0.0066 \mathrm{mmol})$ in acetone $(2 \mathrm{~mL})$ was treated with a 10 -fold excess of MeI (9.3 $\mathrm{mg}, 0.066 \mathrm{mmol})$, and $\mathrm{K}_{2} \mathrm{CO}_{3}(9.1 \mathrm{mg}, 0.066 \mathrm{mmol})$, and was stirred at ambient temperature overnight. Workup and fractionation as detailed above yielded $4^{\prime}, 4^{\prime \prime}$-dimethyl-lamellarin O (19) $\left(t_{\mathrm{R}} 15.4 \mathrm{~min}, 2.4 \mathrm{mg}, 75 \%\right)$.

4'-methyl-lamellarin O (18): ${ }^{1} \mathrm{H}$ NMR $\left(600 \mathrm{MHz}, \mathrm{CDCl}_{3}\right): \delta_{\mathrm{H}}=8.03(\mathrm{~d}, J=8.7 \mathrm{~Hz}, 2 \mathrm{H}), 7.15(\mathrm{~d}$, $J=8.7 \mathrm{~Hz}, 2 \mathrm{H}), 7.00(\mathrm{~d}, J=8.7 \mathrm{~Hz}, 2 \mathrm{H}), 6.95(\mathrm{~d}, J=8.7 \mathrm{~Hz}, 2 \mathrm{H}), 6.92(\mathrm{~s}, 1 \mathrm{H}), 6.82(\mathrm{~d}, J=8.7 \mathrm{~Hz}$, $2 \mathrm{H}), 6.64(\mathrm{~d}, J=8.7 \mathrm{~Hz}, 2 \mathrm{H}), 5.74(\mathrm{~s}, 2 \mathrm{H}), 3.90(\mathrm{~s}, 3 \mathrm{H}), 3.82(\mathrm{~s}, 3 \mathrm{H}), 3.47(\mathrm{~s}, 3 \mathrm{H}) ;{ }^{13} \mathrm{C} \mathrm{NMR}$ $\left(150 \mathrm{MHz}, \mathrm{CDCl}_{3}\right): \delta_{\mathrm{C}}=192.1,164.3,162.7,158.5,154.0,132.0,131.3,130.5,129.8,128.1,128.1$, $127.4,127.3,124.9,120.0,115.2,114.3,113.0,55.7,55.7,55.3,51 ; \mathrm{UV}(\mathrm{MeOH}) \lambda_{\max }(\log \varepsilon)$ 277 (4.48) nm; HRESI(-)MS m/z 494.1574 [M + Na] $]^{+}$(calcd for $\mathrm{C}_{28} \mathrm{H}_{25} \mathrm{NO}_{6} \mathrm{Na}^{+}, 494.1574$ ).

4"-methyl-lamellarin O (17): ${ }^{1} \mathrm{H}$ NMR (600 MHz, $\left.\mathrm{CDCl}_{3}\right): \delta_{\mathrm{H}}=8.03(\mathrm{~d}, J=8.7 \mathrm{~Hz}, 2 \mathrm{H}), 7.10(\mathrm{~d}$, $J=8.7 \mathrm{~Hz}, 2 \mathrm{H}), 7.00(\mathrm{~d}, J=8.7 \mathrm{~Hz}, 2 \mathrm{H}), 7.00(\mathrm{~d}, J=8.7 \mathrm{~Hz}, 2 \mathrm{H}), 6.93(\mathrm{~s}, 1 \mathrm{H}), 6.77(\mathrm{~d}, J=8.7 \mathrm{~Hz}$, 
2H), $6.72(\mathrm{~d}, J=8.7 \mathrm{~Hz}, 2 \mathrm{H}), 5.74(\mathrm{~s}, 2 \mathrm{H}), 3.90(\mathrm{~s}, 3 \mathrm{H}), 3.75(\mathrm{~s}, 3 \mathrm{H}), 3.46(\mathrm{~s}, 3 \mathrm{H}) ;{ }^{13} \mathrm{C} \mathrm{NMR}(150 \mathrm{MHz}$, $\left.\mathrm{CDCl}_{3}\right): \delta_{\mathrm{C}}=192.1,164.2,162.5,158.0,154.5,132.2,131.3,130.5,129.6,128.2,128.1,127.3,127.1$, 124.9, 120.0, 114.6, 114.3, 113.7, 55.7, 55.7, 55.3, 51; UV (MeOH) $\lambda_{\max }(\log \varepsilon) 277$ (4.46) nm; HRESI(-)MS $m / z 494.1574[\mathrm{M}+\mathrm{Na}]^{+}$(calcd for $\mathrm{C}_{28} \mathrm{H}_{25} \mathrm{NO}_{6} \mathrm{Na}^{+}, 494.1574$ ).

4',4"-dimethyl-lamellarin O (19): ${ }^{1} \mathrm{H}$ NMR $\left(600 \mathrm{MHz}, \mathrm{CDCl}_{3}\right): \delta_{\mathrm{H}}=8.03(\mathrm{~d}, J=8.7 \mathrm{~Hz}, 2 \mathrm{H}), 7.16$ $(\mathrm{d}, J=8.7 \mathrm{~Hz}, 2 \mathrm{H}), 7.00(\mathrm{~d}, J=8.7 \mathrm{~Hz}, 2 \mathrm{H}), 7.00(\mathrm{~d}, J=8.7 \mathrm{~Hz}, 2 \mathrm{H}), 6.93(\mathrm{~s}, 1 \mathrm{H}), 6.82(\mathrm{~d}, J=8.7 \mathrm{~Hz}$, 2H), $6.72(\mathrm{~d}, J=8.7 \mathrm{~Hz}, 2 \mathrm{H}), 5.74(\mathrm{~s}, 2 \mathrm{H}), 3.90(\mathrm{~s}, 3 \mathrm{H}), 3.82(\mathrm{~s}, 3 \mathrm{H}), 3.75(\mathrm{~s}, 3 \mathrm{H}), 3.47(\mathrm{~s}, 3 \mathrm{H}) ;{ }^{13} \mathrm{C}$ NMR (150 MHz, $\left.\mathrm{CDCl}_{3}\right): \delta_{\mathrm{C}}=192.0,164.2,162.5,158.4,158.0,132.0,131.3,130.5,129.6,128.1$, $128.1,127.4,127.1,124.9,120.0,114.3,113.7,113.0,55.7,55.7,55.3,55.3,51.0 ; \mathrm{UV}(\mathrm{MeOH}) \lambda_{\max }$ (log ع) 277 (4.68) nm; HRESI(-)MS m/z 508.1732 [M+ Na $]^{+}$(calcd for $\mathrm{C}_{29} \mathrm{H}_{27} \mathrm{NO}_{6} \mathrm{Na}^{+}, 508.1731$ ).

\subsection{Molecular Modeling}

Lamellarin O (11) and 4',4"-dimethyl-lamellarin O (19) were prepared as ligands for docking simulations into human ABCG2 following the same protocol as previously described [29]. All grids of ABCG2 were prepared and generated as per our pervious protocol [30]. Grid-1 generated using Arg482 had the highest docking score; therefore, docking discussion was based on binding model of 11 and 19 at this site. Glide v6.0 (Schrödinger, LLC, New York, NY, USA, 2013) docking tool was followed with the default functions. Top scoring conformation was used for graphical analysis. All computations were carried out on a Dell Precision 490n dual processor with Linux OS (Ubuntu 12.04 LTS, Canonical Group Limited, London, UK).

\subsection{Statistical Analysis}

The statistical significance was defined as $p<0.05$ by two-tailed Student's $t$-test. All experiments were performed at least three times in duplicate.

\section{Conclusions}

In this study we assessed the P-gp, BCRP or MRP1 inhibitory properties of a family of marine alkaloids, ianthellidone A-F (1-9) and lamellarins O1 (9), O2 (10), O (11) and R (12), isolated from a southern Australian marine sponge Ianthella sp. (CMB-01245), leading to the discovery of 11 as a potent and selective BCRP inhibitor. The P-gp, MRP1 and BCRP inhibitory properties of 11 were detected, measured and quantified by calcein AM accumulation and cell flow cytometry based (accumulation or efflux) assays against human colon cancer (SW620 and SW620 Ad300), ovarian carcinoma (2008 and 2008/MRP1) and non-small cell lung (NCI-H460 and NCI-460/MX20) cells, respectively, with further validation of P-gp inhibitory properties measured in Hoechst 33342 accumulation and efflux, and doxorubicin drug resistance reversal assays, and of BCRP inhibitory properties in $\left[{ }^{3} \mathrm{H}\right]$-mitoxantrone drug accumulation and efflux assays. Collectively these studies demonstrated that, whereas $\mathbf{1 1}$ exhibited weak to moderate inhibitory activity against P-gp and MRP1, it was a selective and potent inhibitor of BCRP $\left(\mathrm{IC}_{50} 4.7 \pm 0.6 \mu \mathrm{M}\right)$. Further studies demonstrated that 11 did not alter (reduce) the expression of BCRP in NCI-460/MX20 cells, suggesting that it was acting (as predicted) as a small molecule inhibitor of BCRP function. An SAR analysis on the BCRP 
inhibitory properties of 11, drawing on data for the co-metabolites 1-10 and 12, and the synthetic analogues 12-19, and supported by in silico docking studies on 11 and 19, identified structural elements that were key to the inhibitory pharmacophore, including the methoxy-acetophenone, carboxylic ester and phenolic residues. Our discovery and characterization of $\mathbf{1 1}$ as a selective inhibitor of BCRP will hopefully prompt and inform future SAR investigations into this pharmacophore, to explore and advance its potential to deliver a clinically useful BCRP inhibitor therapeutic.

\section{Acknowledgments}

We thank Susan E. Bates and Robert W. Robey (NCE, NIH, Bethesda, MD, USA) for providing FTC, SW620, SW620 Ad300, NCI-H460, NCI-H460/MX20, and John Allen (USyd) and Piet Borst (NCI, Amsterdam, The Netherlands) for providing 2008 and 2008/MRP. Xiao-Cong Huang acknowledges the provision of International Postgraduate Scholarship from The University of Queensland. This work was partially funded by The Institute for Molecular Bioscience and The University of Queensland. We also thank Mark F. Rosenberg (University of Manchester, Manchester, UK) and Zsolt Bikádi (Virtua Drug Ltd., Budapest, Hungary) for providing coordinates of ABCG2 homology model.

\section{Author Contributions}

Conceived and designed the experiments: X.-C.H., X.X., Y.-K.Z., T.T.T., Z.-S.C. and R.J.C. Performed the experiments: X.-C.H., X.X., Y.-K.Z. Analyzed the data: X.-C.H., X.X., Y.-K.Z. Wrote the paper: X.-C.H., X.X., Y.-K.Z., A.A.S., Z.-S.C. and R.J.C.

\section{Conflicts of Interest}

The authors declare no conflict of interest.

\section{References}

1. Dano, K. Active outward transport of daunomycin in resistant ehrlich ascites tumor-cells. Biochim. Biophys. Acta 1973, 323, 466-483.

2. Juliano, R.L.; Ling, V. A surface glycoprotein modulating drug permeability in Chinese hamster ovary cell mutants. Biochim. Biophys. Acta 1976, 455, 152-162.

3. Hegedus, C.; Ozvegy-Laczka, C.; Apati, A.; Magocsi, M.; Nemet, K.; Orfi, L.; Keri, G.; Katona, M.; Takats, Z.; Varadi, A.; et al. Interaction of nilotinib, dasatinib and bosutinib with $\mathrm{ABCB} 1$ and ABCG2: Implications for altered anti-cancer effects and pharmacological properties. Br. J. Pharmacol. 2009, 158, 1153-1164.

4. Cole, S.P.C.; Bhardwaj, G.; Gerlach, J.H.; Mackie, J.E.; Grant, C.E.; Almquist, K.C.; Stewart, A.J.; Kurz, E.U.; Duncan, A.M.V.; Deeley, R.G. Overexpression of a transporter gene in a multidrug-resistant human lung-cancer cell-line. Science 1992, 258, 1650-1654.

5. Szakacs, G.; Paterson, J.K.; Ludwig, J.A.; Booth-Genthe, C.; Gottesman, M.M. Targeting multidrug resistance in cancer. Nat. Rev. Drug Discov. 2006, 5, 219-234. 
6. Wu, C.P.; Ohnuma, S.; Ambudkar, S.V. Discovering natural product modulators to overcome multidrug resistance in cancer chemotherapy. Curr. Pharm. Biotechnol. 2011, 12, 609-620.

7. Prinsep, M.R.; Caplan, F.R.; Moore, R.E.; Patterson, G.M.L.; Smith, C.D. Tolyporphin, a novel multidrug resistance reversing agent from the blue-green-alga tolypothrix-nodosa. $\mathrm{J} . \mathrm{Am}$. Chem. Soc. 1992, 114, 385-387.

8. Aoki, S.; Yoshioka, Y.; Miyamoto, Y.; Higuchi, K.; Setiawan, A.; Murakami, N.; Chen, Z.S.; Sumizawa, T.; Akiyama, S.; Kobayashi, M. Agosterol a, a novel polyhydroxylated sterol acetate reversing multidrug resistance from a marine sponge of Spongia sp. Tetrahedron Lett. 1998, 39, 6303-6306.

9. Chen, Z.S.; Aoki, S.; Komatsu, M.; Ueda, K.; Sumizawa, T.; Furukawa, T.; Okumura, H.; Ren, X.Q.; Belinsky, M.G.; Lee, K.; et al. Reversal of drug resistance mediated by multidrug resistance protein (MRP) 1 by dual effects of agosterol a on mrp1 function. Int. J. Cancer 2001, 93, 107-113.

10. Spitaler, M.; Utz, I.; Hilbe, W.; Hofmann, J.; Grunicke, H.H. PKC-independent modulation of multidrug resistance in cells with mutant (v185) but not wild-type (g185) p-glycoprotein by bryosratin 1. Biochem. Pharmacol. 1998, 56, 861-869.

11. Aoki, S.; Okano, M.; Matsui, K.; Itoh, T.; Satari, R.; Akiyama, S.; Kobayashi, M. Brianthein A, a novel briarane-type diterpene reversing multidrug resistance in human carcinoma cell line, from the gorgonian briareum excavatum. Tetrahedron 2001, 57, 8951-8957.

12. Henrich, C.J.; Robey, R.W.; Takada, K.; Bokesch, H.R.; Bates, S.E.; Shukla, S.; Ambudkar, S.V.; McMahon, J.B.; Gustafson, K.R. Botryllamides: Natural product inhibitors of ABCG2. ACS Chem. Biol. 2009, 4, 637-647.

13. Tanaka, C.; Yamamoto, Y.; Otsuka, M.; Tanaka, J.; Ichiba, T.; Marriott, G.; Rachmat, R.; Higa, T. Briarane diterpenes from two species of octocorals, Ellisella sp. and Pteroeides sp. J. Nat. Prod. 2004, 67, 1368-1373.

14. Fu, P.; Liu, P.P.; Li, X.; Wang, Y.; Wang, S.X.; Hong, K.; Zhu, W.M. Cyclic bipyridine glycosides from the marine-derived actinomycete actinoalloteichus cyanogriseus WH1-2216-6. Org. Lett. 2011, 13, 5948-5951.

15. Smith, C.D.; Zilfou, J.T.; Stratmann, K.; Patterson, G.M.L.; Moore, R.E. Welwitindolinone analogs that reverse p-glycoprotein-mediated multiple-drug resistance. Mol. Pharmacol. 1995, 47, 241-247.

16. Williams, A.B.; Jacobs, R.S. A marine natural product, patellamide-D, reverses multidrug-resistance in a human leukemic-cell line. Cancer Lett. 1993, 71, 97-102.

17. Raju, R.; Piggott, A.M.; Huang, X.C.; Capon, R.J. Nocardioazines: A novel bridged diketopiperazine scaffold from a marine-derived bacterium inhibits p-glycoprotein. Org. Lett. 2011, 13, 2770-2773.

18. Plisson, F.; Huang, X.C.; Zhang, H.; Khalil, Z.; Capon, R.J. Lamellarins as inhibitors of p-glycoprotein-mediated multidrug resistance in a human colon cancer cell line. Chem. Asian J. 2012, 7, 1616-1623.

19. Huang, X.C.; Sun, Y.L.; Salim, A.A.; Chen, Z.S.; Capon, R.J. Parguerenes: Marine red alga bromoditerpenes as inhibitors of P-glycoprotein (ABCB1) in multidrug resistant human cancer cells. Biochem. Pharmacol. 2013, 85, 1257-1268. 
20. Druley, T.E.; Stein, W.D.; Roninson, I.B. Analysis of MDR1 P-glycoprotein conformational changes in permeabilized cells using differential immunoreactivity. Biochemistry 2001, 40, 4312-4322.

21. Henrich, C.J.; Bokesch, H.R.; Dean, M.; Bates, S.E.; Robey, R.W.; Goncharova, E.I.; Wilson, J.A.; McMahon, J.B. A high-throughput cell-based assay for inhibitors of ABCG2 activity. J. Biomol. Screen. 2006, 11, 176-183.

22. Robey, R.W.; Honjo, Y.; van de Laar, A.; Miyake, K.; Regis, J.T.; Litman, T.; Bates, S.E. A functional assay for detection of the mitoxantrone resistance protein, MXR (ABCG2). Biochim. Biophys. Acta 2001, 1512, 171-182.

23. Zhang, H.; Conte, M.M.; Huang, X.C.; Khalil, Z.; Capon, R.J. A search for bace inhibitors reveals new biosynthetically related pyrrolidones, furanones and pyrroles from a Southern Australian marine sponge, Ianthella sp. Org. Biomol. Chem. 2012, 10, 2656-2663.

24. Robey, R.W.; Steadman, K.; Polgar, O.; Morisaki, K.; Blayney, M.; Mistry, P.; Bates, S.E. Pheophorbide a is a specific probe for ABCG2 function and inhibition. Cancer Res. 2004, 64, 1242-1246.

25. Hooijberg, J.H.; Broxterman, H.J.; Kool, M.; Assaraf, Y.G.; Peters, G.J.; Noordhuis, P.; Scheper, R.J.; Borst, P.; Pinedo, M.M.; Jansen, G. Antifolate resistance mediated by the multidrug resistance proteins MRP1 and MRP2. Cancer Res. 1999, 59, 2532-2535.

26. Tiberghien, F.; Loor, F. Ranking of P-glycoprotein substrates and inhibitors by a calcein-AM fluorometry screening assay. Anti-Cancer Drugs 1996, 7, 568-578.

27. Carmichael, J.; DeGraff, W.G.; Gazdar, A.F.; Minna, J.D.; Mitchell, J.B. Evaluation of a tetrazolium-based semiautomated colorimetric assay: Assessment of radiosensitivity. Cancer Res. 1987, 47, 943-946.

28. Kuang, Y.H.; Patel, J.P.; Sodani, K.; Wu, C.P.; Liao, L.Q.; Patel, A.; Tiwari, A.K.; Dai, C.L.; Chen, X.; Fu, L.W.; et al. OSI-930 analogues as novel reversal agents for ABCG2-mediated multidrug resistance. Biochem. Pharmacol. 2012, 84, 766-774.

29. Sodani, K.; Tiwari, A.K.; Singh, S.; Patel, A.; Xiao, Z.J.; Chen, J.J.; Sun, Y.L.; Talele, T.T.; Chen, Z.S. GW583340 and GW2974, human EGFR and HER-2 inhibitors, reverse ABCG2- and ABCB1-mediated drug resistance. Biochem. Pharmacol. 2012, 83, 1613-1622.

30. Tiwari, A.K.; Sodani, K.; Dai, C.L.; Abuznait, A.H.; Singh, S.; Xiao, Z.J.; Patel, A.; Talele, T.T.; $\mathrm{Fu}, \mathrm{L}$.; Kaddoumi, A.; et al. Nilotinib potentiates anticancer drug sensitivity in murine ABCB1-, ABCG2-, and ABCC10-multidrug resistance xenograft models. Cancer Lett. 2013, 328, 307-317.

(C) 2014 by the authors; licensee MDPI, Basel, Switzerland. This article is an open access article distributed under the terms and conditions of the Creative Commons Attribution license (http://creativecommons.org/licenses/by/3.0/). 